\title{
Catalyst-Free Crosslinking Modification of Nata-de-Coco-Based Bacterial Cellulose Nanofibres Using Citric Acid for Biomedical Applications
}

\author{
Rabiu Salihu 1,2,3, Mohamed Nainar Mohamed Ansari 4,*, Saiful Izwan Abd Razak 2,*(D), \\ Nurliyana Ahmad Zawawi ${ }^{1}$, Shafinaz Shahir ${ }^{1}$ (D), Mohd Helmi Sani ${ }^{1}$, Muhammad Hanif Ramlee ${ }^{5}$, \\ Mohammed Ahmad Wsoo ${ }^{1,6}$, Abdul Halim Mohd Yusof ${ }^{7}$, Nadirul Hasraf Mat Nayan ${ }^{8}$ \\ and Ahmad Mohammed Gumel ${ }^{3}$
}

Citation: Salihu, R.; Ansari, M.N.M.; Abd Razak, S.I.; Ahmad Zawawi, N.; Shahir, S.; Sani, M.H.; Ramlee, M.H.; Wsoo, M.A.; Mohd Yusof, A.H.; Nayan, N.H.M.; et al. Catalyst-Free Crosslinking Modification of Nata-de-Coco-Based Bacterial Cellulose Nanofibres Using Citric Acid for Biomedical Applications. Polymers 2021, 13, 2966. https:// doi.org/10.3390/polym13172966

Academic Editor: Luís Alves

Received: 19 June 2021

Accepted: 18 August 2021

Published: 31 August 2021

Publisher's Note: MDPI stays neutral with regard to jurisdictional claims in published maps and institutional affiliations.

Copyright: (c) 2021 by the authors. Licensee MDPI, Basel, Switzerland. This article is an open access article distributed under the terms and conditions of the Creative Commons Attribution (CC BY) license (https:// creativecommons.org/licenses/by/ $4.0 /)$.
1 Department of Biosciences, Faculty of Science, Universiti Teknologi Malaysia, Skudai 81300, Johor, Malaysia; salihu.r@fud.edu.ng (R.S.); nurliyana@utm.my (N.A.Z.); shafinazshahir@utm.my (S.S.); helmisani@utm.my (M.H.S.); mohammed1981@uor.edu.krd (M.A.W.)

2 Bioinspired Device and Tissue Engineering Research Group, Faculty of Engineering, School of Biomedical Engineering and Health Sciences, Universiti Teknologi Malaysia, Skudai 81310, Johor, Malaysia

3 Department of Microbiology and Biotechnology, Federal University Dutse, PMB 7156 Ibrahim Aliyu Bypass, Dutse 720101, Jigawa State, Nigeria; am.gumel@fud.edu.ng

4 Institute of Power Engineering, Universiti Tenaga Nasional, Kajang 43000, Selangor, Malaysia

5 Medical Devices and Technology Centre (MEDiTEC), Institute of Human-Centered Engineering (iHmEn), Universiti Teknologi Malaysia, Skudai 81300, Johor, Malaysia; m.hanif@utm.my

6 Department of Chemistry, College of Science, University of Raparin, Rania 46012, Kurdistan Region, Iraq

7 Faculty of Engineering, School of Chemical and Energy Engineering, Universiti Teknologi Malaysia, Skudai 81300, Johor, Malaysia; halimy@cheme.utm.my

8 Faculty of Engineering Technology, Universiti Tun Hussein Onn Malaysia, Batu Pahat, Bahru 86400, Johor, Malaysia; nadirul@uthm.edu.my

* Correspondence: ansari@uniten.edu.my (M.N.M.A.); saifulizwan@utm.my (S.I.A.R.); Tel.: +60-17-4815680 (S.I.A.R.)

Abstract: Bacterial cellulose (BC) has gained attention among researchers in materials science and bio-medicine due to its fascinating properties. However, $\mathrm{BC}^{\prime}$ 's fibre collapse phenomenon (i.e., its inability to reabsorb water after dehydration) is one of the drawbacks that limit its potential. To overcome this, a catalyst-free thermal crosslinking reaction was employed to modify BC using citric acid (CA) without compromising its biocompatibility. FTIR, XRD, SEM/EDX, TGA, and tensile analysis were carried out to evaluate the properties of the modified $\mathrm{BC}(\mathrm{MBC})$. The results confirm the fibre crosslinking phenomenon and the improvement of some properties that could be advantageous for various applications. The modified nanofibre displayed an improved crystallinity and thermal stability with increased water absorption/swelling and tensile modulus. The MBC reported here can be used for wound dressings and tissue scaffolding.

Keywords: bacterial cellulose; citric acid; catalyst-free; crosslinking; nata-de-coco; biomedicine

\section{Introduction}

The Philippines-originated jelly dessert (nata de coco) is the cheapest form of bacterial cellulose (BC) produced through the fermentation of coconut water [1]. It is a pure form of (BC) with unique physicochemical, morphological, and mechanical properties [1,2]. Owing to this, nata de coco-based $\mathrm{BC}$ can serve as a good reference point for applications such as biomedicine, where high material purity is a primary demand. Also, its large-scale production in many Asian countries like Malaysia, Indonesia, and Thailand [3] is due to the ease of the processes.

$\mathrm{BC}$ is a microfibrillar biomaterial first reported by Andrian Brown in 1886. Different species of bacteria such as Acetobacter xylinum, Rhizobium, Achromobacter, and Sarcina 
have been reported to produce $\mathrm{BC}$ through fermentation [4-6]. BC is generally pure, biocompatible, and non-toxic, and it can be modified into a broad range of different forms and compositions. This means it has a remarkable range of applications in many fields of science and medicine [7-10]. However, its inability to reabsorb much water after being dehydrated and its inadequate functionality limit its attractiveness. Hence, there is a need to modify it further [11].

In situ and ex situ modifications were the principal approaches for $\mathrm{BC}$ modification. Ex situ modification is usually done after BC production and involves either physical or chemical processes [12-14]. One of the methods of interest is the crosslinking reaction (a process that induces a strong link between polymer chains through covalent bonding), owing to its simplicity and effectiveness [15].

Citric acid (CA) is one of the organic acids classified as "generally regarded as safe" (GRAS) by the US food and drug administration (FDA) that has long been used as a modifier on many polymeric biomaterials via crosslinking, including BC [16-20]. Modifying polymeric biomaterials with CA typically yields what is known as citrate-based biomaterials (CBBs) [21,22]. Owing to their excellent biological, chemical, and material properties, (e.g., antimicrobial, antioxidant, and fluorescence properties), CBBs have been used increasingly frequently in biomedicine [23-25]. Crosslinking a biopolymer with CA requires elevated temperatures of $120-190{ }^{\circ} \mathrm{C}$ [26]. This method has the advantage of allowing the material's mechanical, chemical, and degradation properties (among other properties) to be fine-tuned $[27,28]$.

The CA crosslinking of biopolymers involving different catalysts has been reported by many scientists, but the undesirable effects posed by the catalysts $[29,30]$ have limited their application in biomedicine. Therefore, we hypothesised that the use of the catalyst for $\mathrm{BC}$ crosslinking modification is unnecessary.

In this study, a catalyst-free thermal crosslinking approach was employed for the first time to modify nata de coco-based $\mathrm{BC}$ fibres using a readily available and inexpensive multifunctional monomer (i.e., CA). An evaluation of the physicochemical, morphological, and mechanical properties of the resulting biopolymer showed that it retained some of its important properties (e.g., thermal stability) while exhibiting a better crystallinity index, water absorption rate, and tensile modulus than unmodified BC. Our method seems to be the cheapest and easiest approach that yields promising improvements to $B C^{\prime} s$ properties. Moreover, the findings show that the use of a catalyst for BC modification might be unnecessary.

\section{Materials and Methods}

\subsection{Chemicals and Materials}

Bacterial cellulose (BC) sheets were purchased from a local nata de coco company (Happy Alliance). CA monohydrate powder $\left(\mathrm{C}_{6} \mathrm{H}_{8} \mathrm{O}_{7} \cdot \mathrm{H}_{2} \mathrm{O}\right)$ and sodium hydroxide $(\mathrm{NaOH})$ were all purchased from Merck (Sigma-Aldrich, St. Louis, MI, USA).

\subsection{Purification and Modification of Bacterial Cellulose (BC)}

$B C$ hydrogels were modified with $C A$ by thermal crosslinking as in [31] with slight modifications to exclude the catalyst. Briefly, the wet $B C$ sample was cut into $100 \mathrm{~mm} \times 50 \mathrm{~mm}$ pieces and purified in $1 \%(w / v) \mathrm{NaOH}$ at $90{ }^{\circ} \mathrm{C}$ for $60 \mathrm{~min}$ before being washed with distilled water until the $\mathrm{pH}$ reached $7-8$ at $37^{\circ} \mathrm{C}$. BC sheets were immersed in different molar $(\mathrm{M})$ concentrations $(0.0375,0.075,0.15,0.3$, and 0.6$)$ of a CA solution in ion-exchanged distilled water $\left(\mathrm{diH}_{2} \mathrm{O}\right)$ and allowed to stand for $24 \mathrm{~h}$ at $45^{\circ} \mathrm{C}$. They were then cured in an oven at $140^{\circ} \mathrm{C}$ for $2 \mathrm{~h}$. Another $\mathrm{BC}$ sample with the same dimensions was treated under the same conditions using only $\mathrm{diH}_{2} \mathrm{O}$ - this sample served as the control sample. All samples were then removed and rinsed with $\mathrm{diH}_{2} \mathrm{O}$ until the $\mathrm{pH}$ reached 5-6. After this, the samples were tagged as $\mathrm{BC}$ (pristine), MBC0.03 (0.0375 M), MBC0.07 (0.075 M), MBC0.15 (0.15 M), $\mathrm{MBC} 0.30(0.3 \mathrm{M})$, or MBC0.60 (0.6 M), and freeze-dried for characterisation. 


\subsection{Characterisation}

For comparison, the BC films were characterised based on their physicochemical, morphological, and mechanical properties through scanning electron microscopy (SEM), energy-dispersive X-ray (EDX), Fourier transform infrared (FTIR), X-ray diffraction (XRD), water contact angle (WCA), swelling rate (SR), thermogravimetric analysis (TGA), and tensile modulus.

\subsubsection{Scanning Electron Microscopy (SEM)}

The surface morphology of the fibres before and after modification was examined by SEM analysis (Model: Hitachi TM3000, Tokyo, Japan) equipped with an EDX system. Micrographs of platinum sputter-coated samples were taken at an accelerating voltage of $15 \mathrm{kV}$ for different magnifications.

\subsubsection{Fourier Transformed Infrared (FTIR)}

The BC, MBC samples were analysed using (Model: PerkinElmer-Frontier ${ }^{\mathrm{TM}}$, L1280044, Waltham, MA, USA) spectrophotometer equipped with an attenuated total reflection (ATRFTIR) system as in [32]. The spectra were obtained from scans between a wavelength range of 4000 to $650 \mathrm{~cm}^{-1}$ and $4 \mathrm{~cm}^{-1}$ resolutions.

\subsubsection{X-ray Diffraction (XRD)}

The XRD analysis was performed using an X-ray diffractometer (Model: Rigaku SmartLab, Austin, TX, USA.) with a CuK $\alpha$ radiation wavelength $(\lambda=0.154 \mathrm{~nm})$ operated at $40 \mathrm{kV}$ and $30 \mathrm{~mA}$. Scans were undertaken between angle $2 \theta$ values of $10^{\circ}$ to $60^{\circ}$ at a speed of $3^{\circ} / \mathrm{min}$. The crystallinity index (CrI) was calculated based on values obtained from the peaks analysis on origin software using Equation (1), while the crystallite size (CS), and the crystal allomorphs of cellulose I were calculated from the XRD data using Equations (2) and (3), respectively [33].

$\operatorname{CrI}(\%)=$ Area of crystalline peaks $/$ Area of all peaks (crystalline + amorphous $) \times 100 \%$

$$
\mathrm{CS}=\mathrm{K} \lambda / \mathrm{FWHM} \cos \theta
$$

$\mathrm{K}$ is the Scherrer's constant (0.9), $\lambda$ is the X-ray wavelength (1.54 $\AA$ ), FWHM is the width of the diffraction peak at maximum height, and $\theta$ is the Bragg's angle.

$$
Z=1693 d_{1}-902 d_{2}-594
$$

The term $Z$ denotes discriminant function developed by [34], $d_{1}$ is the $d$-spacing of 1-10 peak, and $d_{2}$ is the $d$-spacing of 110 peaks, where $Z>0$ or $Z<0$ indicates $I_{\alpha}$ or $I_{\beta}$ rich type of cellulose, respectively [35].

\subsubsection{Water Contact Angle (WAC)}

An Optima machine (Model: 1020046094) equipped with a camera was used to capture water droplet images and measure the WCA. Briefly, $20 \times 20 \mathrm{~mm}$ sheets were cut after freeze-drying before this process was performed. A uniform droplet of $2.0 \mu \mathrm{L}$ of deionised water $\left(\mathrm{diH}_{2} \mathrm{O}\right)$ was dispensed on five (5) different points on each sample, and the average angle was then recorded [36].

\subsubsection{Swelling Rate (SR)}

Freeze-dried samples were cut into $30 \times 30 \mathrm{~mm}$ pieces. Their dried weight $\left(\mathrm{W}_{1}\right)$ values were then recorded before they were immersed in either distilled water or simulated body fluid (SBF) at ambient temperature. Samples were then removed and weighed at specific intervals after having been blotted with filter paper to remove excess water until an 
equilibrium weight $\left(\mathrm{W}_{2}\right)$ was reached. The swelling rate was calculated using Equation (4) below $[37,38]$.

$$
\mathrm{SR}=\left(\mathrm{W}_{2}-\mathrm{W}_{1}\right) / \mathrm{W}_{1} \times 100 \%
$$

where $W_{1}$ is the dried weight and $W_{2}$ is the final wetted weight.

\subsubsection{Thermal Gravimetric Analysis (TGA)}

The thermal stability of all samples was evaluated using a thermal analyser (Shimadzu DTG-60H, Kyoto, Japan). For all the samples, a freeze-dried film weighing $18 \pm 3 \mathrm{mg}$ was heated in a platinum pan to $30{ }^{\circ} \mathrm{C}$ to $900{ }^{\circ} \mathrm{C}$ at a heating rate of $10^{\circ} \mathrm{C} / \mathrm{min}$ under a nitrogen atmosphere of $100 \mathrm{~mL} / \mathrm{min}$ flow rate. The weight loss upon heating was normalised as percentage weight loss $(\%)$ and plotted against the corresponding temperature $\left({ }^{\circ} \mathrm{C}\right)[39]$.

\subsubsection{Tensile Properties}

The tensile properties of the $\mathrm{BC}$ and MBC samples were evaluated using a tensile testing machine (Zwick/Roell Z020, Zwick, Ulm, Germany) according to ASTM-D882 standards. Briefly, freeze-dried samples that were kept in a desiccator were cut into a rectangular shape $(70 \times 20 \mathrm{~mm})$ with different thicknesses and a gauge" length of $50 \mathrm{~mm}$. Samples were strained at maximum load of $2.0 \mathrm{kN}$ and a crosshead speed of $2 \mathrm{~mm} / \mathrm{min}$. The stress was determined as loading force in Newton (N) against the crosssectional area (width $\times$ thickness) of the sample and the strain. The strain was calculated as $\Delta \mathrm{L} / \mathrm{L}_{0}$ where $\Delta \mathrm{L}$ is the exerted extension from starting point and $\mathrm{L}_{0}$ is the initial length $[40,41]$ The modulus was then determined from the linear region of the $0.2 \%$ offset of the stress/strain curve. All measurements were performed for at least five samples under ambient conditions.

\section{Results and Discussion}

\subsection{Scanning Electron Microscopy (SEM)}

In the SEM micrographs shown in Figure 1, cellulose fibres can be observed with different surface morphologies among the samples. The unmodified sample (BC) appears to have a compacted fibre network with uniformly interconnected pores similar to what [42] reported. The modified samples, on the other hand, displayed different fibre networks depending on the CA concentration. At lower concentrations (MBC0.03, MBC0.07, and MBC0.15), porous fibre networks can be observed, which could allow for more water absorption. Higher concentrations (MBC0.30 and MBC0.70), in contrast, showed compacted fibres, similar to the untreated sample. This could be due to the high crosslinking density between the fibres, thus affecting the porosity and preventing the passage of water molecules and leading to a low swelling rate (as explained in Section 3.5 and Figure 6). This could also be why [29] obtained a different result since they used percentage concentrations, whereas the present study used molar concentrations of CA.

\subsection{Fourier Transformed Infrared (FTIR)}

The FTIR spectra of the pristine and modified samples are shown in Figure 2. The signature peaks attributed to the dominant functional group of BC's (OH-stretching) vibration were located at $3346 \mathrm{~cm}^{-1}$. Peaks at $2865 \mathrm{~cm}^{-1}$ and $1420 \mathrm{~cm}^{-1}$ were due to $\mathrm{C}-\mathrm{H}$ stretching, and the peak at $1450 \mathrm{~cm}^{-1}$ was due to $\mathrm{CH} 2$ absorption. Peaks at $1719 \mathrm{~cm}^{-1}$ were related to carbonyl/carboxyl $(\mathrm{C}=\mathrm{O})$ stretching [43] and appear only on the crosslinked samples, thus confirming the presence of CA within the modified BC samples $[31,44,45]$. Peaks between $1055 \mathrm{~cm}^{-1}$ and $1020 \mathrm{~cm}^{-1}$ were due to $\mathrm{C}-\mathrm{O}-\mathrm{C}$ interactions. The reduced intensity of the $\mathrm{OH}$ peaks on the crosslinked samples can also result from the chemical interaction between cellulose and CA [46]. Overall, the increase in the intensity of the peaks associated to $\mathrm{C}=\mathrm{O}$-stretching $\left(1710.6 \mathrm{~cm}^{-1}\right)$ with increasing concentration of $\mathrm{CA}$ on treated samples indicate that crosslinking modification on the BC was successful. The proposed mechanism of CA crosslinking on BC was presented in a schematic diagram in Figure 3. 

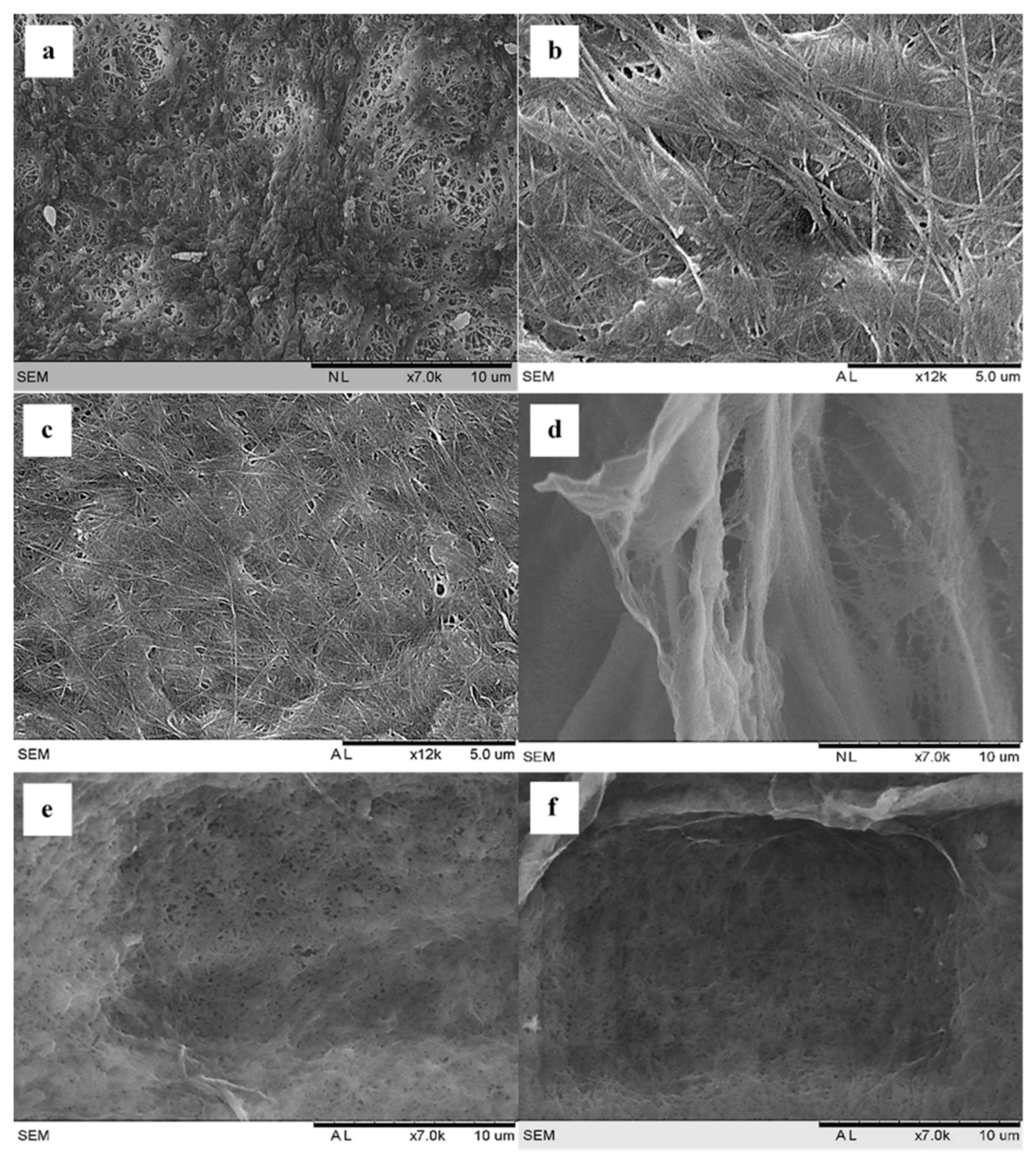

Figure 1. Scanning electron microscope (SEM) images for (a) bacterial cellulose (BC), (b) MBC0.03, (c) MBC0.07, (d) MBC0.15, (e) MBC0.30, and (f) MBC0.60.

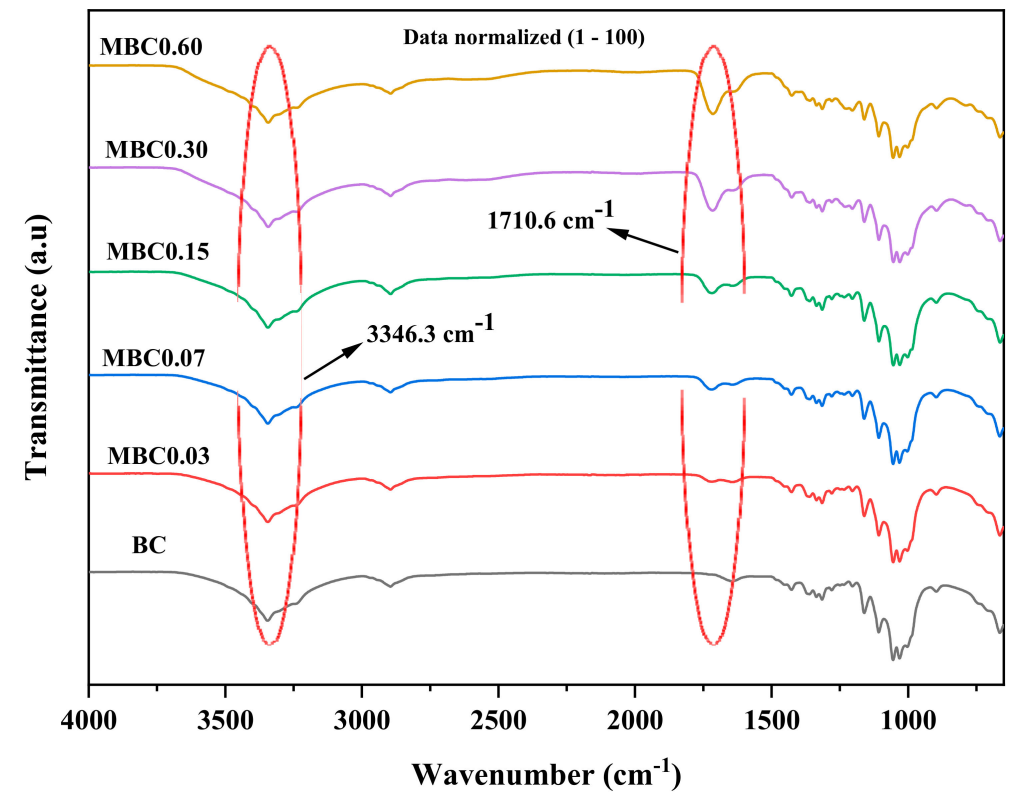

Figure 2. Fourier transform infrared (FTIR) spectrum of the unmodified and modified samples at different citric acid (CA) concentrations. 


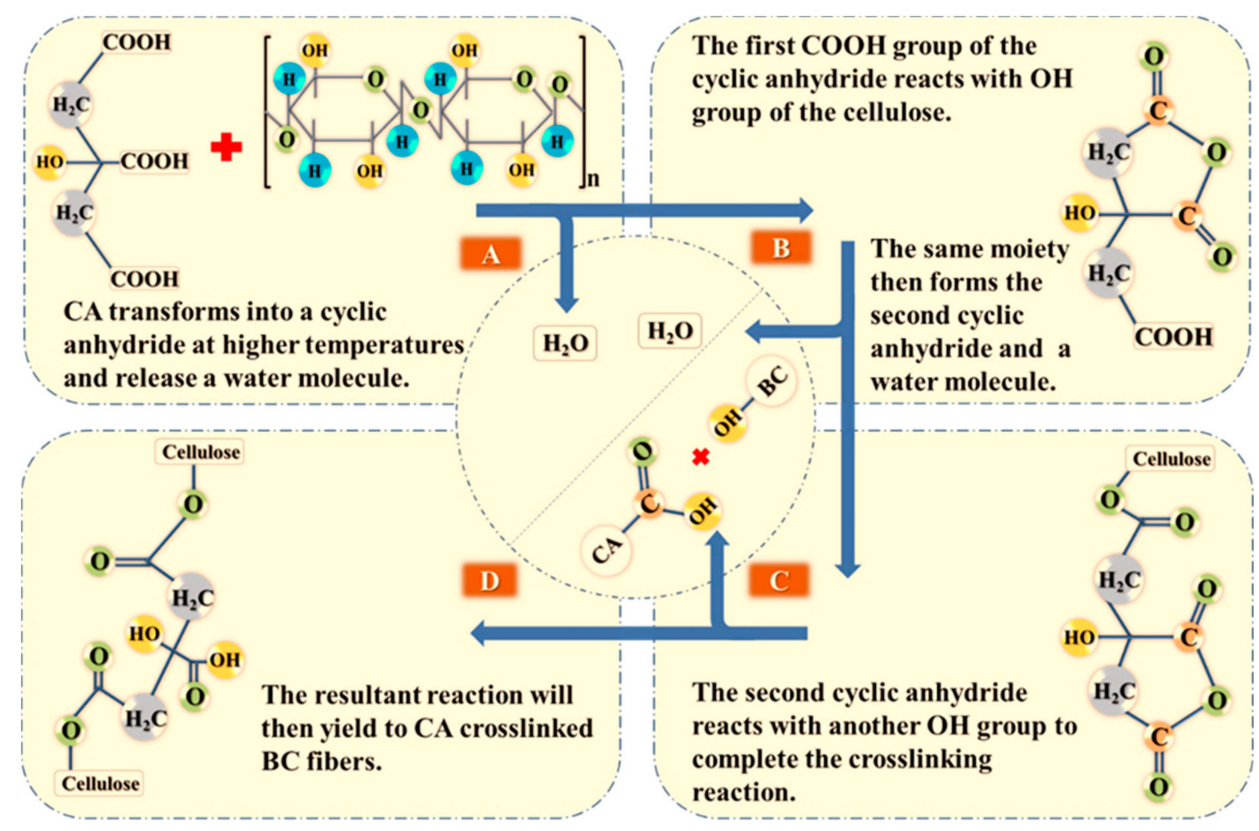

Figure 3. Schematic diagram of the proposed CA crosslinking mechanism on BC.

\subsection{X-ray Diffraction (XRD)}

The XRD patterns shown in Figure 4 represent the spectra obtained for the pure and modified samples. All samples showed peaks typical of cellulose I allomorph at lattice planes of $110,1-10$, and 200 , corresponding to $2 \theta$ values of $14.6^{\circ}, 16.6^{\circ}$, and $22.6^{\circ}$, respectively, as previously reported $[33,35,47,48]$. Distinctive peaks with different intensities were obtained at diffraction planes of 130, 042, and 040, corresponding to $2 \theta$ values of $19.4^{\circ}$, $26.1^{\circ}$ and $34.3^{\circ}$. These peaks appeared only on the modified samples and, thus, were attributed to the CA crosslinking of the BC [49].

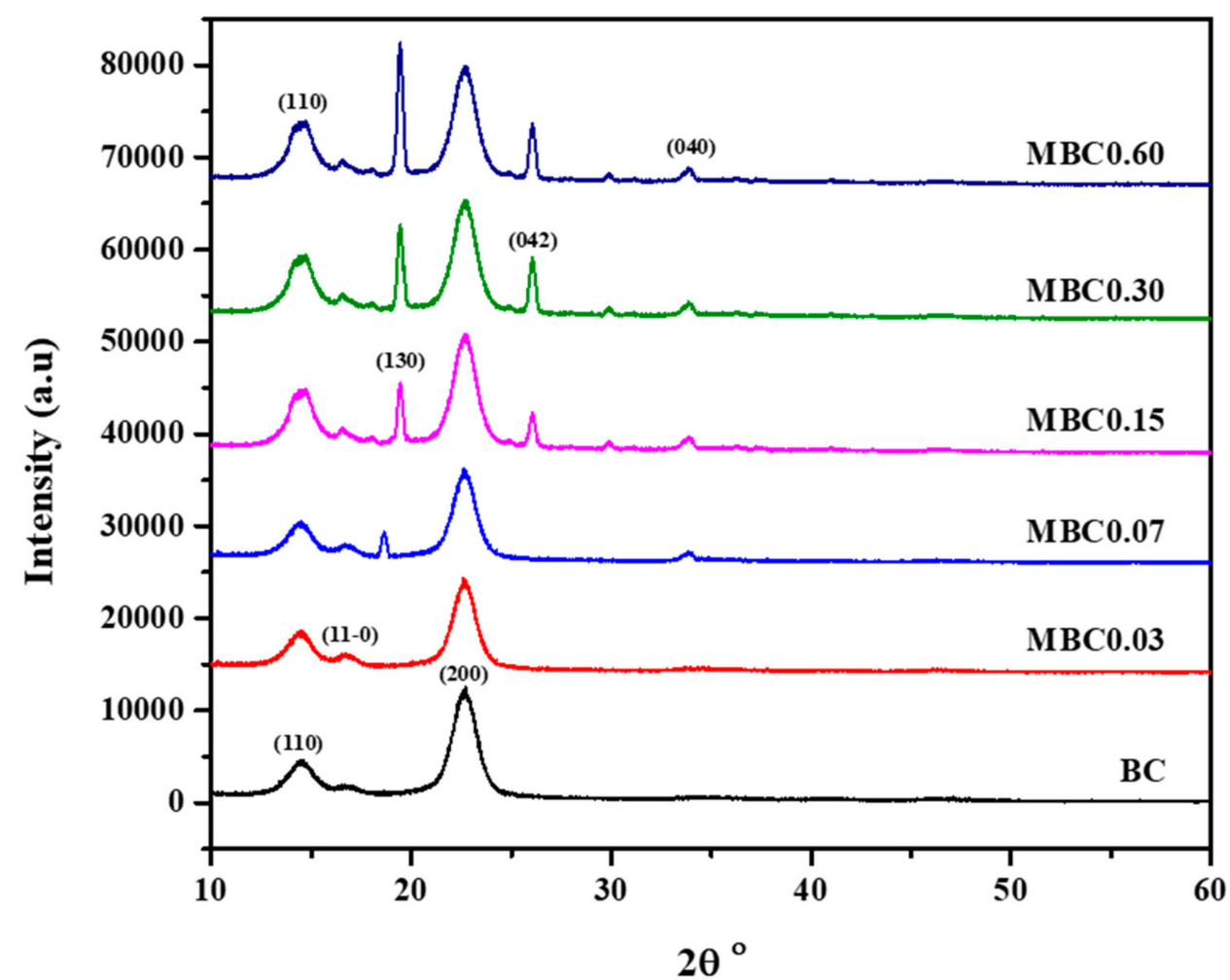

Figure 4. X-ray diffraction (XRD) spectra of the unmodified and modified BC. 
The peaks associated with BC's crystallinity appeared with similar intensities for all samples, indicating that CA modification has a positive effect on the crystalline structure and morphology of BC [50,51]. Even though [16] reported a decrease in crystalline peaks on sodium carboxymethylcellulose (NaCMC) crosslinked with $\mathrm{CA}$, such findings are likely due to one of the cellulose derivatives used. De Lima et al. observed decreased crystallinity and ascribed it to the increased viscosity of $\mathrm{NaCMC}$ or its interaction with cellulose nanofibres during crystallisation [52].

The calculated crystallinity indexes and crystallite size values are presented in Table 1. These values essentially show that the CA crosslinking has improved the crystallinity and crystallite size of the MBC. Furthermore, the cellulose I allomorph (calculated using the Z-discriminant function) showed that all the samples have the same cellulose $\mathrm{I}_{\alpha}$ rich (triclinic) form, which is typical of bacterial cellulose [53-55]. All other calculated values aligned with previously reported data [31] and indicate that crosslinking modification with CA has improved the BC's crystallinity.

Table 1. Calculated crystallinity indexes and crystallite sizes of the modified and unmodified samples.

\begin{tabular}{cccc}
\hline Sample & Crystallinity Index (\%) & Crystallite Size (Å) & Allomorph \\
\hline BC & 80 & 51 & I $\alpha$ rich (triclinic) \\
MBC0.03 & 80 & 56 & I $\alpha$ rich (triclinic) \\
MBC0.60 & 81 & 56 & I $\alpha$ rich (triclinic) \\
MBC0.60 & 84 & 56 & I $\alpha$ rich (triclinic) \\
MBC0.60 & 91 & 56 & I $\alpha$ rich (triclinic) \\
MBC0.60 & 93 & 56 & I $\alpha$ rich (triclinic) \\
\hline
\end{tabular}

\subsection{Water Contact Angle (WCA)}

The wetting behaviour of a material's surface is closely related to the molecular terminal groups present and contact angle studies give information about the wettability properties of materials [56]. In theory, a surface is considered hydrophilic or super hydrophilic when its WCA is below $90^{\circ}$ or $10^{\circ}$, respectively [36]. Figure 5 depicts the mean contact angles measured for the pure and modified BC samples. All samples, including the pure BC sample, had WCAs between $0^{\circ}$ and $33.90^{\circ}$, signifying that all samples were either hydrophilic or super hydrophilic.

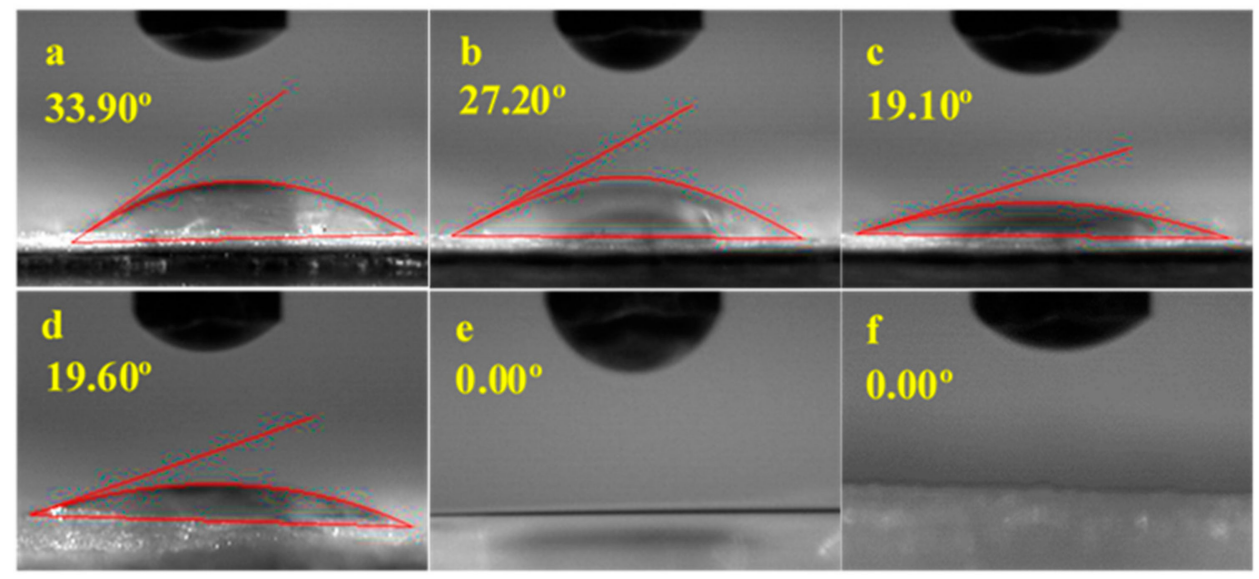

Figure 5. Mean water contact angles obtained for (a) BC, (b) MBC0.03, (c) MBC0.07, (d) MBC0.15, (e) $\mathrm{MBC} 0.30$, and (f) MBC0.60.

However, it is noteworthy that the modified samples have shown decreasing WCAs of as low as $0^{\circ}(\mathrm{MBC} 0.30$ and $\mathrm{MBC} 0.60)$, in which case water droplets are no longer capturable (they disperse as soon as they are dropped). BC's hydrophilicity could be attributed to the additional carboxyl groups $[43,57]$ that can form hydrogen bonds with water molecules [58]. Even though a native BC is inherently hydrophilic, the WCA tends to 
decrease with increasing the CA concentration. Essentially, the CA modification performed on $\mathrm{BC}$ in the present study has improved its surface chemistry to attract more water.

\subsection{Swelling Rate (SR)}

Generally, polymeric materials' water absorption and swelling behaviour occur through capillary action and diffusion and the electrostatic repulsion between the ions on the polymer chains that force them to expand and swell [57]. The swelling rates (SRs) of pure and modified BC samples are presented in Figure 6.

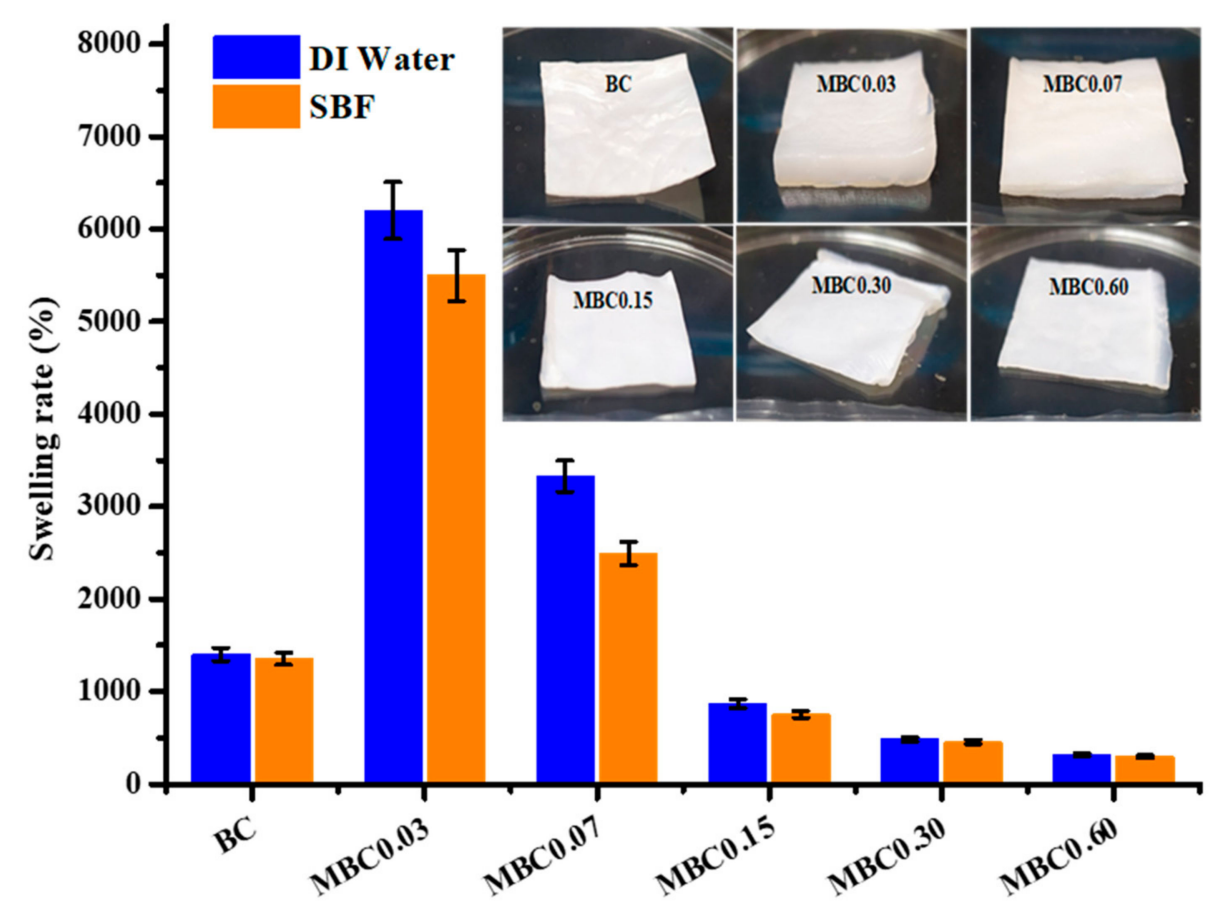

Figure 6. Swelling rates and sample images of the unmodified and modified BC after soaking in deionised (DI) water and simulated body fluid (SBF).

Modified samples typically presented increased SRs at lower CA concentrations and decreased SRs (even dropping below that of pure BC) at higher CA concentrations. This decrease in SR could be due to the numerous crosslinker points formed within BC's fibre networks, thus reducing the amount of space for water to enter [58]. It is evident from the samples with the lowest absorption rates (i.e., $\mathrm{MBC} 0.30$ and $\mathrm{MBC} 0.60$ ) that there is a packed fibre geometry on the SEM micrographs (in Figure 1), which could result from the high concentration of CA. The sample images in Figure 6 serve as additional evidence of the SR trend between samples at different CA concentrations.

Water absorption/swelling is especially advantageous for BC's medical applications, such as its use as wound dressings [29]. The use of SBF to determine SR is mainly based on ascertaining whether the differences in the ionic concentrations of deionised water and SBF can affect the SR results. Interestingly, all samples in the present study showed similar SRs, both for SBF and deionised water. The SR results reported here corroborate a previous report that BC's water holding capacity is 60 to 700 times its dry weight [59].

\subsection{Thermal Gravimetric Analysis (TGA)}

An important property of $\mathrm{BC}$ is its thermal stability, especially when it is used in biomedicine applications, where higher temperatures are applied for sterilisation processes. Figure 7 shows the thermal behaviour of the pristine and modified $\mathrm{BC}$ evaluated in the present study. 


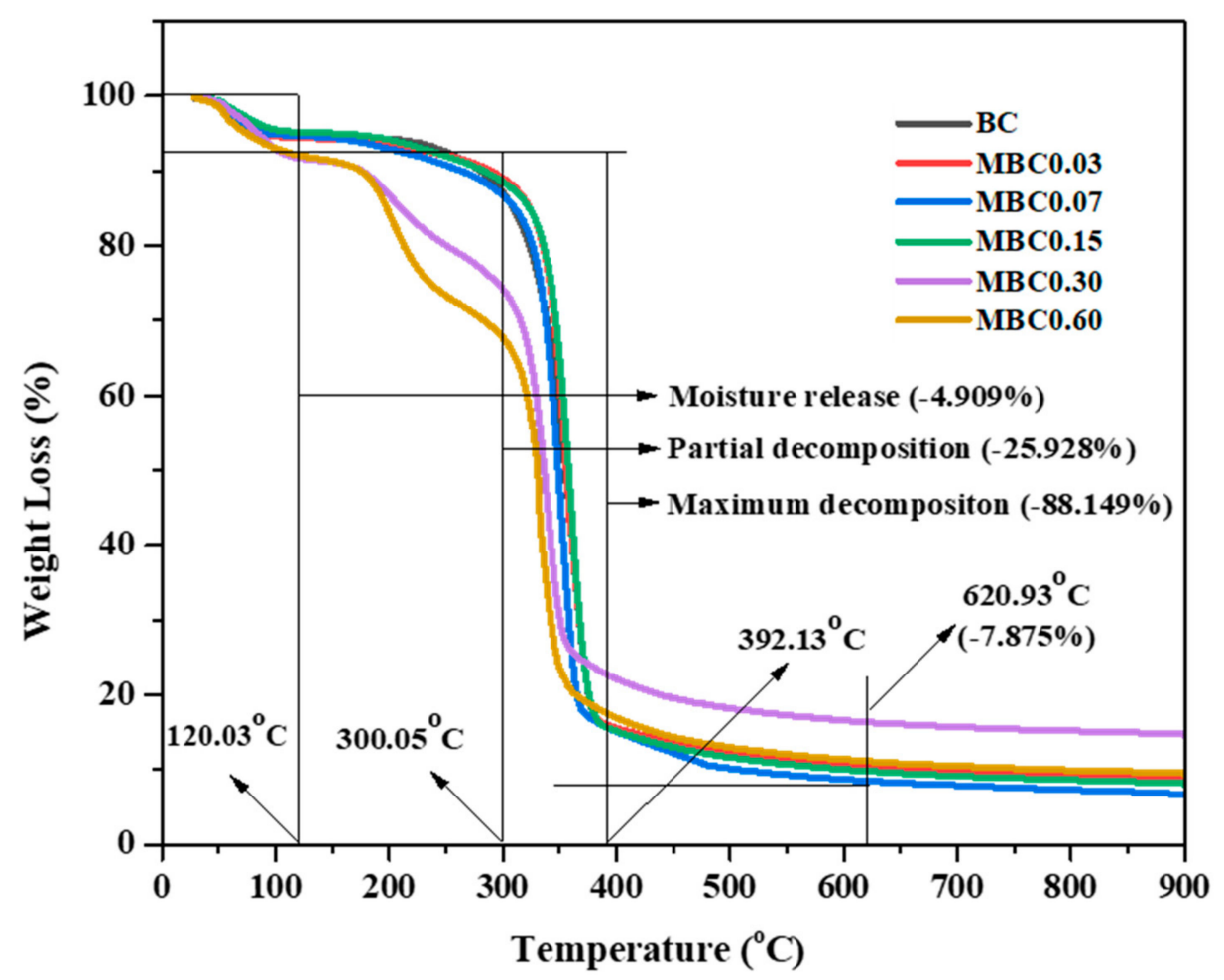

Figure 7. Thermal gravimetric analysis (TGA) graphs of the unmodified and modified BC samples.

The initial weight loss observed for all samples at temperatures of $45-120^{\circ} \mathrm{C}$ was due to absorbed moisture evaporation. Except for the samples with the highest $\mathrm{CA}$ concentrations (MBC0.30 and $\mathrm{MBC} 0.60$ ), which displayed a partial decomposition of $120-300{ }^{\circ} \mathrm{C}$, all modified samples were not different from the pristine BC. They all showed a maximum weight loss at 300-392 ${ }^{\circ} \mathrm{C}$ due to dehydration, decomposition, and the dissociation of glycosidic links [60-62]. The partial, total, and residual mass losses observed at maximum temperatures of $300{ }^{\circ} \mathrm{C}, 392{ }^{\circ} \mathrm{C}$, and $620.93{ }^{\circ} \mathrm{C}$ were $25.928 \%, 88.149 \%$, and $7.875 \%$, respectively. The partial decomposition observed may also be due to the highest concentration of $\mathrm{CA}$, which attracts more moisture than the lower concentrations. Our result implies that CA modification has little effect on the thermal properties of the BC [63].

\subsection{Tensile Testing}

Table 2 presents the tensile test results and Figure 8 represents the stress/strain curves of all the samples. All modified samples exhibited better mechanical strength than the unmodified sample, except for the sample with the lowest CA concentration (MBC0.03), which exhibited a very low tensile strength value.

Table 2. Mechanical properties of the unmodified and modified samples as mean \pm standard deviation.

\begin{tabular}{ccccc}
\hline Samples & Thickness $(\mathbf{m m})$ & $\mathbf{E}_{\mathbf{t}} \mathbf{( M P a )}$ & $\boldsymbol{\sigma} \mathbf{M}(\mathbf{M P a})$ & $\varepsilon_{\mathbf{B}}(\mathbf{\%})$ \\
\hline BC & $0.99 \pm 0.07$ & $56.68 \pm 7.81$ & $1.25 \pm 0.16$ & $1.94 \pm 0.06$ \\
MBC0.03 & $2.16 \pm 0.19$ & $17.97 \pm 1.48$ & $0.62 \pm 0.16$ & $3.97 \pm 0.60$ \\
MBC0.07 & $0.16 \pm 0.01$ & $473.59 \pm 62.02$ & $20.60 \pm 3.58$ & $4.87 \pm 0.25$ \\
MBC0.15 & $0.12 \pm 0.01$ & $778.42 \pm 132.47$ & $28.43 \pm 3.15$ & $4.11 \pm 0.59$ \\
MBC0.30 & $0.08 \pm 0.01$ & $945.73 \pm 199.62$ & $26.65 \pm 10.13$ & $3.27 \pm 0.71$ \\
MBC0.60 & $0.18 \pm 0.09$ & $1024 \pm 44.66$ & $16.37 \pm 0.63$ & $3.23 \pm 0.36$ \\
\hline
\end{tabular}




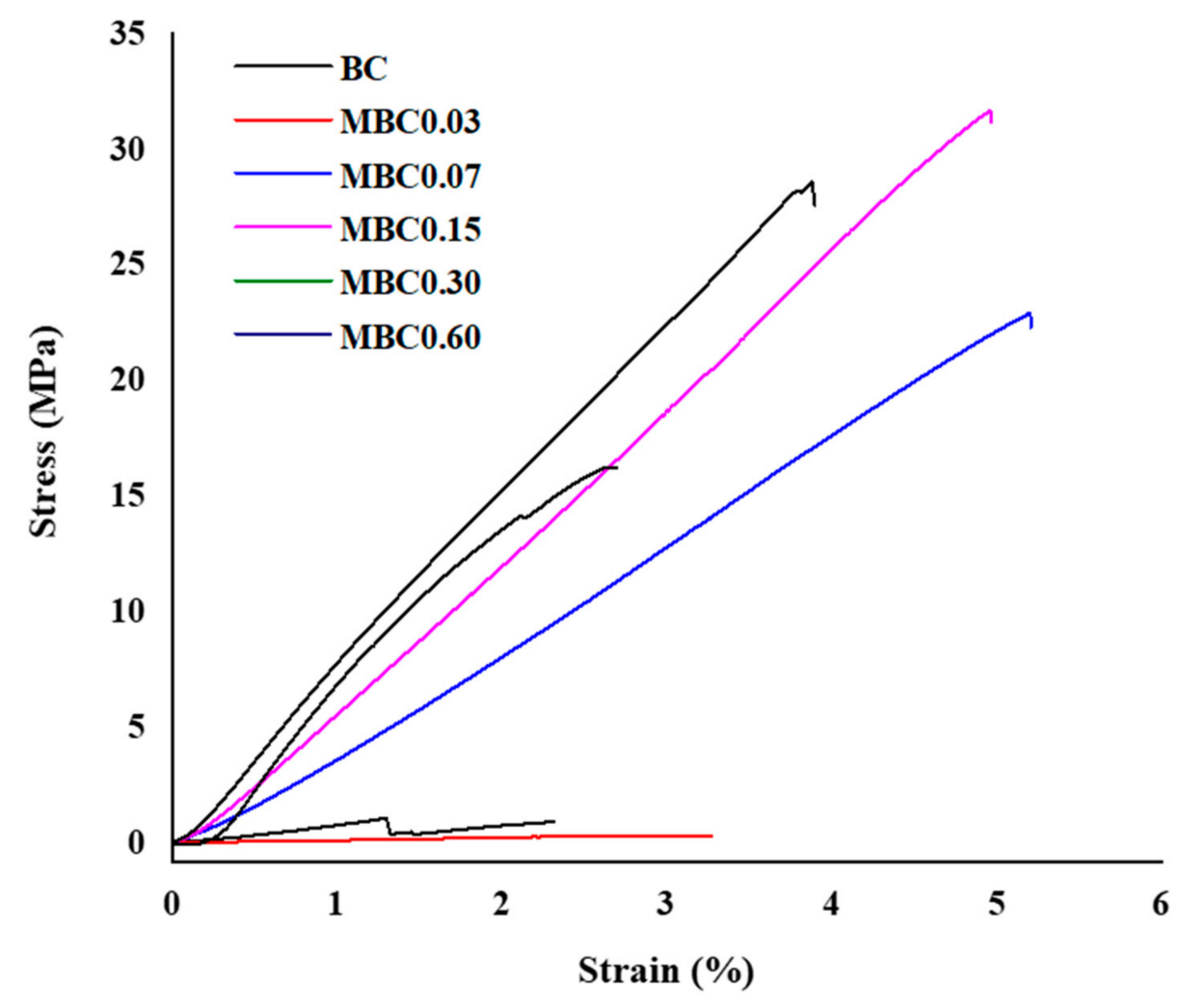

Figure 8. Mechanical properties of the modified and unmodified samples.

The decrease in the mechanical strength displayed could result from the smaller crosslinking degrees within the fibre networks due to the low amount of crosslinker. This supposition is supported by the SEM micrographs Figure 1. It can be observed that, despite having a lower modulus value, the elongation at the break is within the same range as observed in other modified samples. This implies that the elasticity of the fibres is close to that of the fibres in other modified samples after the maximum yield limit is reached.

Like the modulus, the tensile strength follows the trend of increasing as the CA concentration increases, except for the lowest concentration. However, the trend of elongation at the breaking point showed a different pattern, as it decreases as the CA concentration increases. Therefore, it can be hypothesised that applying a high-concentration CA treatment to $\mathrm{BC}$ may reduce the stretching ability of $\mathrm{BC}$ fibres.

\section{Conclusions}

Several attempts to enhance $\mathrm{BCs}$ ' properties through crosslinking modification involve the use of catalysts. However, some of these catalysts might alter the chemical composition and compromise the resulting polymer's biocompatibility, thus limiting its application, especially in biomedicine. Here, we reported for the first time a catalyst-free modification of BC with CA using a simple immersion hydrothermal crosslinking method.

The improvements in the chemical, morphological, thermal, and mechanical properties presented in this report are an indication that the modification has resulted in a potential citrate-based biopolymer that can be used as wound dressings or tissue scaffold material. Although the cytotoxicity studies of the CA-modified BC is not within the scope of the current report, it is part of the authors' future investigation. The approach used here seems to be the cheapest and easiest modification method that yields some promising results. Thus, the findings show that the proposed method is effective and that catalysts could be excluded from future BC modification techniques, especially those intended for biomedical applications. 
Author Contributions: Conceptualization, S.I.A.R. and R.S.; methodology, S.I.A.R. and R.S.; software, S.I.A.R. and R.S.; validation, M.N.M.A., S.I.A.R. and M.A.W.; formal analysis, R.S. and M.A.W.; investigation, R.S.; resources, S.I.A.R., M.N.M.A. and M.H.R.; data curation, S.I.A.R. and R.S.; writingoriginal draft preparation, R.S.; writing—review and editing, S.I.A.R., A.M.G. and M.H.S.; visualization, R.S. and S.I.A.R.; supervision, S.I.A.R., N.A.Z., S.S. and M.H.S.; project administration, S.I.A.R., N.H.M.N. and R.S.; funding acquisition, M.N.M.A., S.I.A.R., A.H.M.Y. and M.H.R. All authors have read and agreed to the published version of the manuscript.

Funding: This research was funded by the Innovative Research and Management Centre (iRMC), Universiti Tenaga Nasional, Malaysia, research publication BOLD grant (J510050002), and Universiti Teknologi Malaysia for research grant number 02M44.

Institutional Review Board Statement: Not applicable.

Informed Consent Statement: Not applicable.

Data Availability Statement: All data generated or analysed during the study are included in this article and are available from the corresponding author on reasonable request.

Acknowledgments: The authors would like to thank the Innovative Research and Management Centre (iRMC), Universiti Tenaga Nasional, Malaysia for providing research publication BOLD grant (J510050002), the Universiti Teknologi Malaysia for research grant number 02M44 and Legasi Megajaya Sdn Bhd (M) for providing the facilities.

Conflicts of Interest: The authors declare no conflict of interest.

\section{References}

1. Nugroho, D.A.; Aji, P. Characterization of Nata de Coco Produced by Fermentation of Immobilized Acetobacter xylinum. Agric. Agric. Sci. Procedia 2015, 3, 278-282. [CrossRef]

2. Phisalaphong, M.; Tran, T.-K.; Taokaew, S.; Budiraharjo, R.; Febriana, G.G.; Nguyen, D.-N.; Chu-Ky, S.; Dourado, F. Nata de coco Industry in Vietnam, Thailand, and Indonesia a Muenduen Phisalaphong, Tien-Khai Tran, Son Chu-Ky, and Fernando Dourado have contributed equally to this work. Bact. Nanocellulose 2016, 231-236. [CrossRef]

3. Halib, N.; Amin, M.; Ahmad, I. Physicochemical properties and characterization of nata de coco from local food indus-tries as a source of cellulose. Sains Malays. 2012, 41, 205-211.

4. Brown, R.M., Jr. Cellulose structure and biosynthesis: What is in store for the 21st century? J. Polym. Sci. Part A Polym. Chem. 2004, 42, 487-495. [CrossRef]

5. Jonas, R.; Farah, L.F. Production and application of microbial cellulose. Polym. Degrad. Stab. 1998, 59, 101-106. [CrossRef]

6. Shoda, M.; Sugano, Y. Recent advances in bacterial cellulose production. Biotechnol. Bioprocess Eng. 2005, 10, 1-8. [CrossRef]

7. Pang, M.; Huang, Y.; Meng, F.; Zhuang, Y.; Liu, H.; Du, M.; Ma, Q.; Wang, Q.; Chen, Z.; Chen, L.; et al. Application of bacterial cellulose in skin and bone tissue engineering. Eur. Polym. J. 2020, 122, 109365. [CrossRef]

8. Tayeb, A.H.; Amini, E.; Ghasemi, S.; Tajvidi, M.; Tayeb, A.H.; Amini, E.; Ghasemi, S.; Tajvidi, M. Cellulose Nanomaterials—Binding Properties and Applications: A Review. Molecules 2018, 23, 2684. [CrossRef]

9. Ahmed, J.; Gultekinoglu, M.; Edirisinghe, M. Bacterial cellulose micro-nano fibres for wound healing applications. Biotechnol. Adv. 2020, 41, 107549. [CrossRef]

10. Gregory, D.A.; Tripathi, L.; Fricker, A.T.; Asare, E.; Orlando, I.; Raghavendran, V.; Roy, I. Bacterial cellulose: A smart biomaterial with diverse applications. Mater. Sci. Eng. R Rep. 2021, 145, 100623. [CrossRef]

11. Naeem, M.A.; Siddiqui, Q.; Mushtaq, M.; Farooq, A.; Pang, Z.; Wei, Q. Insitu Self-Assembly of Bacterial Cellulose on Banana Fibers Extracted from Peels. J. Nat. Fibers 2019, 17, 1317-1328. [CrossRef]

12. Stumpf, T.R.; Yang, X.; Zhang, J.; Cao, X. In situ and ex situ modifications of bacterial cellulose for applications in tissue engineering. Mater. Sci. Eng. C 2018, 82, 372-383. [CrossRef] [PubMed]

13. Ul-Islam, M.; Khan, T.; Park, J.K. Water holding and release properties of bacterial cellulose obtained by in situ and ex situ modification. Carbohydr. Polym. 2012, 88, 596-603. [CrossRef]

14. Salihu, R.; Foong, C.Y.; Abd Razak, S.I.; Kadir, M.R.A.; Yusof, A.H.M.; Nayan, N.H.M. Overview of inexpensive production routes of bacterial cellulose and its applications in biomedical engi-neering. Cell Chem. Technol. 2019, 53, 1-13. [CrossRef]

15. Oryan, A.; Kamali, A.; Moshiri, A.; Baharvand, H.; Daemi, H. Chemical crosslinking of biopolymeric scaffolds: Current knowledge and future directions of crosslinked engineered bone scaffolds. Int. J. Biol. Macromol. 2018, 107, 678-688. [CrossRef]

16. Dharmalingam, K.; Anandalakshmi, R. Fabrication, characterization and drug loading efficiency of citric acid crosslinked NaCMC-HPMC hydrogel films for wound healing drug delivery applications. Int. J. Biol. Macromole-Cules 2019, 134, 815-829. [CrossRef]

17. Cumming, M.H.; Leonard, A.R.; LeCorre-Bordes, D.S.; Hofman, K. Intra-fibrillar citric acid crosslinking of marine collagen electrospun nanofibres. Int. J. Biol. Macromol. 2018, 114, 874-881. [CrossRef] [PubMed] 
18. Ren, L.; Zhang, Y.; Wang, Q.; Zhou, J.; Tong, J.; Chen, D.; Su, X. Convenient Method for Enhancing Hydrophobicity and Dispersibility of Starch Nanocrystals by Crosslinking Modification with Citric Acid. Int. J. Food Eng. 2018, 14, 20170238. [CrossRef]

19. Sedyakina, N.; Kuskov, A.; Velonia, K.; Feldman, N.; Lutsenko, S.; Avramenko, G. Modulation of Entrapment Efficiency and In Vitro Release Properties of BSA-Loaded Chitosan Micro-particles Cross-Linked with Citric Acid as a Potential Protein-Drug Delivery System. Materials 2020, 13, 1989. [CrossRef]

20. Uranga, J.; Nguyen, B.T.; Si, T.T.; Guerrero, P.; De La Caba, K. The Effect of Cross-Linking with Citric Acid on the Properties of Agar/Fish Gelatin Films. Polymers 2020, 12, 291. [CrossRef]

21. Salihu, R.; Razak, S.I.A.; Zawawi, N.A.; Kadir, M.R.A.; Ismail, N.I.; Jusoh, N.; Mohamad, M.R.; Nayan, N.H.M. Citric acid: A green cross-linker of biomaterials for biomedical applications. Eur. Polym. J. 2021, 146, 110271. [CrossRef]

22. Ma, C.; Tian, X.; Kim, J.P.; Xie, D.; Ao, X.; Shan, D.; Lin, Q.; Hudock, M.R.; Bai, X.; Yang, J. Citrate-based materials fuel human stem cells by metabonegenic regulation. Proc. Natl. Acad. Sci. USA 2018, 115, E11741-E11750. [CrossRef] [PubMed]

23. Shah, A.H.; Bhusari, S.; Djordjevic, I.; Steele, T.W. Twin screw extrusion of conductive citrate-based biomaterials. Eur. Polym. J. 2018, 110, 176-182. [CrossRef]

24. Sabzi, M.; Afshari, M.J.; Babaahmadi, M.; Shafagh, N. pH-dependent swelling and antibiotic release from citric acid crosslinked poly (vinyl alcohol)(PVA)/nano silver hydrogels. Colloids Surf. B Biointerfaces 2020, 188, 110757. [CrossRef]

25. Huang, L.; Wang, C.; Xu, H.; Peng, G. Targeting citrate as a novel therapeutic strategy in cancer treatment. Biochim. et Biophys. Acta (BBA) Bioenerg. 2020, 1873, 188332. [CrossRef] [PubMed]

26. Khouri, J. Chitosan Edible Films Crosslinked by Citric Acid; University of Waterloo: Waterloo, ON, Canada, 2019 ; p. 188.

27. Tran, R.T.; Yang, J.; Ameer, G.A. Citrate-Based Biomaterials and Their Applications in Regenerative Engineering. Annu. Rev. Mater. Res. 2015, 45, 277-310. [CrossRef]

28. Ma, C.; Gerhard, E.; Lu, D.; Yang, J. Citrate chemistry and biology for biomaterials design. Biomaterials 2018, 178, 383-400. [CrossRef]

29. Ciecholewska-Juśko, D.; Żywicka, A.; Junka, A.; Drozd, R.; Sobolewski, P.; Migdał, P.; Kowalska, U.; Toporkiewicz, M.; Fijałkowski, K. Superabsorbent crosslinked bacterial cellulose biomaterials for chronic wound dressings. Carbohydr. Polym. 2021, $253,117247$. [CrossRef] [PubMed]

30. Feng, X.; Xiao, Z.; Sui, S.; Wang, Q.; Xie, Y. Esterification of wood with citric acid: The catalytic effects of sodium hypophosphite (SHP). Holzforschung 2014, 68, 427-433. [CrossRef]

31. Meftahi, A.; Khajavi, R.; Rashidi, A.; Rahimi, M.K.; Bahador, A. Preventing the collapse of 3D bacterial cellulose network via citric acid. J. Nanostruct. Chem. 2018, 8, 311-320. [CrossRef]

32. Bilgi, E.; Bayir, E.; Urkmez, A.S.; Hames, E.E. Optimization of bacterial cellulose production by Gluconacetobacter xylinus using carob and haricot bean. Int. J. Biol. Macromol. 2016, 90, 2-10. [CrossRef]

33. Khan, H.; Kadam, A.; Dutt, D. Studies on bacterial cellulose produced by a novel strain of Lactobacillus genus. Carbohydr. Polym. 2020, 229, 115513. [CrossRef]

34. Wada, M.; Okano, T.; Sugiyama, J. Allomorphs of native crystalline cellulose I evaluated by two equatoriald-spacings. J. Wood Sci. 2001, 47, 124-128. [CrossRef]

35. Poletto, M.; Ornaghi, J.H.L.; Zattera, A.J. Native Cellulose: Structure, Characterization and Thermal Properties. Materials 2014, 7 , 6105-6119. [CrossRef]

36. Zhao, T.; Jiang, L. Contact angle measurement of natural materials. Colloids Surf. B Biointerfaces 2018, 161, 324-330. [CrossRef]

37. Shao, W.; Wu, J.; Wang, S.; Huang, M.; Liu, X.; Zhang, R. Construction of silver sulfadiazine loaded chitosan composite sponges as potential wound dressings. Carbohydr. Polym. 2017, 157, 1963-1970. [CrossRef]

38. Ye, S.; Jiang, L.; Su, C.; Zhu, Z.; Wen, Y.; Shao, W. Development of gelatin/bacterial cellulose composite sponges as potential natural wound dressings. Int. J. Biol. Macromol. 2019, 133, 148-155. [CrossRef]

39. Abba, M.; Nyakuma, B.B.; Ibrahim, Z.; Ali, J.B.; Razak, S.I.A.; Salihu, R. Physicochemical, Morphological, and Microstructural Characterisation of Bacterial Nanocellulose from Glu-conacetobacter xylinus BCZM. J. Nat. Fibers 2020, 1-12. [CrossRef]

40. Tang, S.; Chi, K.; Xu, H.; Yong, Q.; Yang, J.; Catchmark, J.M. A covalently cross-linked hyaluronic acid/bacterial cellulose composite hydrogel for potential biological appli-cations. Carbohydr. Polym. 2020, 252, 117123. [CrossRef] [PubMed]

41. Molina-Romero, J.M.; Arteaga-Ballesteros, B.E.; Guevara-Morales, A.; San Martín-Martínez, E.; Vieyra, H. Reduced tensile properties of bacterial cellulose membranes after an accelerated composite tem-perature/humidity cyclic assay. J. Polym. Environ. 2021, 29, 2349-2358. [CrossRef]

42. Rathinamoorthy, R.; Aarthi, T.; Shree, C.A.A.; Haridharani, P.; Shruthi, V.; Vaishnikka, R.L. Development and Characterization of Self -assembled Bacterial Cellulose Nonwoven Film. J. Nat. Fibers 2019, 1-14. [CrossRef]

43. Pandit, A.; Kumar, R. A Review on Production, Characterization and Application of Bacterial Cellulose and Its Biocom-posites J. Polym. Environ. 2021, 29, 2738-2755. [CrossRef]

44. Wu, Y.-L.; Xu, S.; Wang, T.; Wang, C.-F. Enhanced Metal Ion Rejection by a Low-Pressure Microfiltration System Using Cellulose Filter Papers Modified with Citric Acid. ACS Appl. Mater. Interfaces 2018, 10, 32736-32746. [CrossRef]

45. Haji, A.; Bidoki, S.M.; Gholami, F. Isotherm and Kinetic Studies in Dyeing of Citric Acid-Crosslinked Cotton with Cation-ic Natural Dye. Fibers Polym. 2020, 21, 2547-2555. [CrossRef] 
46. Raucci, M.G.; Alvarez-Perez, M.A.; Demitri, C.; Giugliano, D.; De Benedictis, V.; Sannino, A.; Ambrosio, L. Effect of citric acid crosslinking cellulose-based hydrogels on osteogenic differentiation. J. Biomed. Mater. Res. Part A 2015, 103, 2045-2056. [CrossRef]

47. Trovatti, E.; Serafim, L.; Freire, C.; Silvestre, A.; Neto, C. Gluconacetobacter sacchari: An efficient bacterial cellulose cell-factory. Carbohydr. Polym. 2011, 86, 1417-1420. [CrossRef]

48. Bagheri, M.; Younesi, H.; Hajati, S.; Borghei, S.M. Application of chitosan-citric acid nanoparticles for removal of chromium (VI). Int. J. Biol. Macromol. 2015, 80, 431-444. [CrossRef]

49. Ramírez, J.A.Á.; Hoyos, C.G.; Arroyo, S.; Cerrutti, P.; Foresti, M.L. Acetylation of bacterial cellulose catalyzed by citric acid: Use of reaction conditions for tailoring the esterification extent. Carbohydr. Polym. 2016, 153, 686-695. [CrossRef] [PubMed]

50. Ramírez, J.A.Á.; Fortunati, E.; Kenny, J.M.; Torre, L.; Foresti, M.L. Simple citric acid-catalyzed surface esterification of cellulose nanocrystals. Carbohydr. Polym. 2017, 157, 1358-1364. [CrossRef]

51. Chen, H.; Yan, X.; Feng, Q.; Zhao, P.; Xu, X.; Ng, D.H.; Bian, L. Citric acid/cysteine-modified cellulose-based materials: Green preparation and their applications in anticoun-terfeiting, chemical sensing, and UV shielding. ACS Sustain. Chem. Eng. 2017, 5, 11387-11394. [CrossRef]

52. Fontes, M.D.L.; Meneguin, A.B.; Tercjak, A.; Gutierrez, J.; Cury, B.; dos Santos, A.M.; Ribeiro, S.; Barud, H.S. Effect of in situ modification of bacterial cellulose with carboxymethylcellulose on its nano/microstructure and methotrexate release properties. Carbohydr. Polym. 2018, 179, 126-134. [CrossRef] [PubMed]

53. Zugenmaier, P. History of Cellulose Research; Springer: Berlin/Heidelberg, Germany, 2008; pp. 7-51. [CrossRef]

54. Moon, R.J.; Martini, A.; Nairn, J.; Simonsen, J.; Youngblood, J. Cellulose nanomaterials review: Structure, properties and nanocomposites. Chem. Soc. Rev. 2011, 40, 3941-3994. [CrossRef] [PubMed]

55. French, A.D. Idealized powder diffraction patterns for cellulose polymorphs. Cellulose 2013, 21, 885-896. [CrossRef]

56. Giridhar, G.; Manepalli, R.; Apparao, G. Contact Angle Measurement Techniques for Nanomaterials. In Thermal and Rheological Measurement Techniques for Nanomaterials Characterization; Elsevier BV: Amsterdam, The Netherlands, 2017; pp. 173-195.

57. Luo, M.-T.; Li, H.-L.; Huang, C.; Zhang, H.-R.; Xiong, L.; Chen, X.-F.; Chen, X.-D. Cellulose-Based Absorbent Production from Bacterial Cellulose and Acrylic Acid: Synthesis and Performance. Polymers 2018, 10, 702. [CrossRef] [PubMed]

58. Lawal, O.S.; Storz, J.; Storz, H.; Lohmann, D.; Lechner, D.; Kulicke, W.-M. Hydrogels based on carboxymethyl cassava starch cross-linked with di- or polyfunctional carboxylic acids: Synthesis, water absorbent behavior and rheological characterizations. Eur. Polym. J. 2009, 45, 3399-3408. [CrossRef]

59. Portela, R.; Leal, C.R.; Almeida, P.L.; Sobral, R.G. Bacterial cellulose: A versatile biopolymer for wound dressing applications. Microb. Biotechnol. 2019, 12, 586-610. [CrossRef]

60. Chen, W.H.; Eng, C.F.; Lin, Y.Y.; Bach, Q.V. Independent parallel pyrolysis kinetics of cellulose, hemicelluloses and lignin at various heating rates an-alyzed by evolutionary computation. Energy Convers. Manag. 2020, 221, 113165. [CrossRef]

61. Vasconcelos, N.F.; Feitosa, J.P.A.; da Gama, F.M.P.; Morais, J.P.S.; Andrade, F.K.; de Souza, M.D.S.M.; de Freitas Rosa, M. Bacterial cellulose nanocrystals produced under different hydrolysis conditions: Properties and morphological features. Carbohydr. Polym. 2017, 155, 425-431. [CrossRef] [PubMed]

62. Amin, M.C.I.M.; Abadi, A.G.; Katas, H. Purification, characterization and comparative studies of spray-dried bacterial cellulose microparticles. Carbohydr. Polym. 2014, 99, 180-189. [CrossRef]

63. Awadhiya, A.; Kumar, D.; Rathore, K.; Fatma, B.; Verma, V. Synthesis and characterization of agarose-bacterial cellulose biodegradable composites. Polym. Bull. 2017, 74, 2887-2903. [CrossRef] 